CStockhammer, Qazizada and Gecher, 2019. The definitive, peer reviewed and edited version of this article is published in Review of Keynesian Economics, 7(1), pp. 57-74, 2019. 


\title{
Demand effects of fiscal policy since 2008
}

\author{
Engelbert Stockhammer ${ }^{\mathrm{a}}$, Walid Qazizada ${ }^{\mathrm{b}}$ and Sebastian Gechert $^{\mathrm{c}}$
}

Version 2.01

$10 / 11 / 2017$

${ }^{\text {a }}$ Kingston University London, KT1 2EE, UK

b OXUS Consulting Group, Building 886J, Ghazanfar Bank Street, Wazir Akbar Khan, Kabul, Afghanistan

c Institut für Makroökonomie und Konjunkturforschung (IMK), Hans Böckler Stiftung, Duesseldorf, Germany

\begin{abstract}
The Great Recession 2007-09 has led to controversies about the role of fiscal policy. Academically this has translated into renewed interest in the effects of fiscal policy. Several studies have since suggested that fiscal multipliers are substantially larger in downswings or depressions than in the upswing. In terms of economic policy reactions countries have differed substantially in the fiscal stance. It is an important open question how big the impact of these policies on economic growth has been. The paper uses the regime-dependent multiplier estimates by Qazizada and Stockhammer (2015) and by Gechert and Rannenberg (2014) to calculate the demand effects of fiscal policy for Germany, USA, UK, Greece, Ireland, Italy, Portugal and Spain since 2008. This allows assessing to what extent fiscal policy explains different economic performances across countries. We find expansionary fiscal policy in 2008/09 in all countries, but since 2010 fiscal policies have differed. While the fiscal effect was roughly neutral in Germany, the UK, and the USA, it was large and negative in Greece, Ireland, Italy, Portugal, and Spain.
\end{abstract}

Keywords: multiplier, fiscal policy, austerity, recession

JEL codes: C36, E62

Acknowledgements. The authors are grateful to Antoine Godin, Tim Gooding and two anonymous referees for helpful comments. 


\section{Introduction}

"In a depressed, deflationary economy conventional fiscal prudence is dangerous folly," Paul Krugman (September 11, 2015 on New York Times)

In 2008-09 advanced economies experienced the worst recession since the Great Depression. This experience has challenged economists and policy makers to reconsider the role of fiscal policy. Before the Great Recession, the majority view was one of a limited role of fiscal policy. In the early phase of the crisis 2008/09, there was a short-lived Keynesian revival. Economic policy was at that point leading (mainstream) economic theory. However, in summer 2010 there was a noticeable shift in fiscal policy. The case for austerity was put forward by several governments and by the European Commission. The programs administered by the Troika were imposing harsh austerity on countries in severe recession. Several commentators have claimed that differences in fiscal policy go a long way in explaining the different economic performances of countries since then (Wren Lewis 2015, Krugman 2010, Gechert et al. 2016).

This paper will use recent estimates of regime-dependent multipliers to calculate the growth contributions of fiscal policy for Greece, Ireland, Italy, Portugal and Spain (which we will refer to as the GIIPS countries) and Germany, UK and USA. This will allow us to assess how much economic policy has differed across countries and to what extent it explains differences in economic performance. We use the multiplier estimates by Qazizada and Stockhammer (2015) and Gechert and Rannenberg (2014). Qazizada and Stockhammer (2015) estimate simple multipliers in a panel of 21 OECD countries for the period 1976-2011 using a two-stage least square estimation (TSLS) approach whereas Gechert and Rannenberg (2014) offer a meta-analysis based on 98 published studies that largely draw their information set from pre-crisis samples. The studies thus take two very different methodological 
approaches, but both identify regime-dependent multipliers. We use these two studies to gauge plausible estimates for multipliers in the upswing and the downswing. The main part of the paper uses these multipliers to calculate the effects of the fiscal policy stance on GDP growth for different countries since 2007. This exercise is similar to an out of sample forecast for the crisis years. We are interested in the effects for Greece, Ireland, Italy, Portugal and Spain which have experienced a particularly severe recession in comparison to that of Germany, UK and USA which have seen a recovery of output since 2008.

The paper is structured as follows. Section 2 summarises the debate on fiscal policy. Section 3 discusses the literature on fiscal multipliers. Section 4 explains the calculation of the multipliers for eight countries since 2007 and the fiscal policy effects. Section 5 discusses the main findings and section 6 concludes.

\section{Swings in the fiscal policy debate}

Fiscal policy has seen big changes over the past decades. While some of these changes are closely related to developments in economic theory, others have been triggered by economic circumstances, in particular, crises, or by ideological shifts. In the post-war era, fiscal policy was assigned a prominent role, with full employment regarded as the primary economic aim. This was underpinned by the old Keynesian argument that in an economy with excess capacity, deficit-financed government spending is a powerful stabilization tool. The theory assumed that the fiscal multiplier is a function of marginal propensities of consumption, import, and taxation and the multiplier impact was considered to be larger than one.

Keynesian theory dominated the macroeconomic policy stance throughout the 1960s and 70s in most countries, even if its hegemony was somewhat uneven (Hall 1989). 
Meanwhile, the neoclassical counterattack came in the form of Monetarism which argued that the economy is anchored in the natural rate of unemployment (Friedman, 1968). Further, Monetarism claimed that the marginal propensity to consume out of current income is low in the short run as agents decide their spending based on permanent income (Friedman, 1957). Therefore, government deficit spending induces only little immediate additional private demand while it increases interest rates and crowds out private investment in the long run. As a result, the size of the multiplier is lower than one in the short run. In the long-run, government spending leads to increases in debt and inflation with no impact on output.

High inflation coupled with rising unemployment in the 1970s, weakened the Keynesian dominance in economic policy. As a result, in the 1980s, macroeconomic priorities shifted toward price stability and balanced budgets shaped by Monetarism. Academically, this was strengthened by New Classical economics, which criticized Keynesian theory and insisted on microfoundations for macroeconomic theory based on rational individuals and clearing markets (Laidler, 1986). When the government spends by issuing bonds, agents expect higher future taxes and reduce their consumption and increase savings (the Ricardian equivalence theorem reinstated by Barro 1989). Hence, the impact of government spending, in new classical Real Business Cycle (RBC) models with Ricardian equivalence, is less than one.

In the late 1980s and early 1990s, there were a series of other developments in economic theory. New Keynesian (NK) economists accepted neoclassical methodology but responded by arguing that despite rational expectations, there can be market failures and wage rigidities (Greenwald and Stiglitz, 1987) that led to the development of New Keynesian Dynamic Stochastic General Equilibrium (DSGE) models. In these models, the implicit perfect capital markets assumption may not hold. In a further step, adding a share of financeconstrained agents, whose consumption will largely depend on current income, Ricardian 
equivalence was questioned to some extent (Mankiw, 2000). The next generation of applied NK-DSGE models, from the mid-2000s onwards featured those additional frictions (Gali et al., 2007). Although the government spending multiplier in these newer NK-DSGE models increases, it is still small as compared to post-crisis DSGE simulations (Woodford 2011), and is not long lasting because of the supply side-driven equilibrium and monetary policy following a Taylor-rule. New Keynesian models still have neoclassical long-run properties.

Before the crisis, there was thus a majority view, often called the New Consensus view, which regarded the market system as essentially self-stabilising. Any short-run demand management was assigned to monetary policy, managed by independent central banks that should follow inflation targeting or a Taylor rule. Fiscal policy, in this view, was restricted to automatic stabilisers and would aim for a medium-term balanced budget (Arestis 2009, Blanchard et al 2010). The Great Recession of 2008 put into question the new orthodoxy. Faced with an unprecedented financial collapse and a sharp recession, policy makers used sizable fiscal intervention in 2008 and 2009. However, this was politically contested and by mid-2010 the pendulum swung back with harsh austerity imposed in particular on southern European countries. In this period, economic policy was characterised to some extent by improvisation and in academia, as in politics, there has been a polarisation of views.

Within academia, the New Consensus view had been criticized by dissenting minorities, from different sides. From the Keynesian side, Post Keynesians have rejected the rational behaviour microfoundations for macroeconomic theory. Post Keynesian theory has been formulated as a coherent body of thought (Arestis 1992, Lavoie 2014, Palley 1996) that reinstates the Keynesian argument that involuntary unemployment is pervasive in market economies and that wage flexibility is not sufficient for full employment. Hysteresis phenomena are regarded as ubiquitous (Setterfield 1993, Stockhammer 2008, 2011) and financial markets are characterised by endogenous instability (Minsky 1986, Charles 2008). 
As a consequence, Post Keynesians have maintained the view that fiscal policy is a key instrument for stabilisation and insisted that multipliers would be positive, large and longlasting, in particular in times of financial crises (Arestis and Sawyer 1998). The Post Keynesians thus had formulated positions that the New Keynesian have developed since the crisis, but with a different methodological starting point.

The fiscal neutrality argument also came under attack from a different side. Already in the 1990s Giavazzi and Pagano $(1990,1997)$ and Alesina and Perotti (1995) coined the term Expansionary Fiscal Contraction (EFC) to suggest negative multipliers. They regress economic growth on a measure of cyclically adjusted primary balance (CAPB) for a panel of OECD countries and conclude that episodes of fiscal consolidations are followed by stronger economic growth. ${ }^{1}$ Afonso (2006), in a panel study of EU15 countries over the period of 1970-2005, finds some evidence in favour of EFC for government final consumption spending, taxes, and social transfers. The inverse correlation of government spending and private consumption, he claims, amplifies when fiscal consolidation episodes occur. Reinhard and Rogoff's (2010) much criticized ${ }^{2}$, but influential paper on a 90\% threshold of the publicdebt-to-GDP ratio, above which additional debt would be detrimental to growth, implies the EFC story as well. Proponents of EFC, in general, argue that with a large and sustained reduction in government spending, consumers will assume a future reduction in distorting taxes and interest rates, which in turn will lead to higher income and private consumption. Despite being a non-consensual view in academia, economic policy in Europe after the crisis

\footnotetext{
${ }^{1}$ The empirical findings of the EFC literature have been questioned. In particular, Guajarado et al. (2011) argue that changes in CAPB, which had been used by Giavazzi and Pagano (1990, 1997), Alesina and Perotti (1996), and Alesina and Ardagna (2010) as the key fiscal consolidation variable, can be an outcome of nonpolicy movements due to other developments such as a boom in stock market or devaluation. Hence, using changes in CAPB as measure of fiscal consolidations gives biased results. Dullien (2012) moreover pointed to substantial data problems regarding the selection of alleged consolidation episodes that actually turned out as special accrual effects without a true fiscal impact.

${ }^{2}$ Herndon et al. (2013) show several flaws in their analysis whose correction invalidates their findings.
} 
has largely followed the EFC reasoning irrespective of a substantial amount of theoretical and empirical evidence for large multipliers during recessions.

Since the crisis, New Keynesian-inspired research (in the USA and international organisations more so than in continental Europe) has made a powerful case for the effectiveness of fiscal policy (Rannenberg et al. 2015). Monetary policy soon hit the zerolower-bound (ZLB). In this situation, the central bank does not lean against the wind anymore and therefore cannot dampen the effects of fiscal policy. This argument is reminiscent of the old Keynesian argument of the liquidity trap. The ZLB issue had always been a theoretical possibility in NK models, but until the crisis (other than for the case of Japan) it was regarded as a hypothetical scenario. Since the crisis, the New Keynesian reasoning has gone beyond policy ineffectiveness and, at least in its radical wing, questions the self-adjusting properties of the market system in times of debt overhang. Summers (2014) has suggested the possibility of secular stagnation, i.e. that the natural rate of interest may be (and will remain for some time) negative. In this situation fiscal policy should pursue medium-term budget deficits. Arguably, this version of New Keynesian economics is close to the Post Keynesian view.

Inspired by these debates, there has been a re-assessment of the estimates of fiscal multipliers. In particular, the IMF has famously admitted that its macroeconomic models have substantially underestimated multipliers of fiscal policy in recessions (Blanchard and Leigh 2013). One of the developments is that recent empirical research allows for different effects of fiscal policy in the upswing and the downswing of the business cycle. This literature will be discussed in the following section.

\section{Estimating fiscal multipliers}


The estimation of the fiscal multiplier has a long tradition in macroeconomics. Recently three main estimation strategies have been widely used. One strand of the literature uses structural vector autoregression (VAR) techniques to identify the innovations in government spending and taxation and estimate its impact on output. A second group uses a single equation estimation strategy and either uses exogenous variables such as military expenditures or econometric techniques like two stage least squares (TSLS) for identification. The third strand of the literature uses estimated or calibrated structural macroeconomic models. The vast majority of the available literature assumes linear multipliers and only recently there have been attempts to allow for multipliers to vary over the business cycle. A comprehensive review of these can be found in Gechert (2015), Hebous (2011) and Spilimbergo et al (2009).

Within the VAR literature, the size of the multiplier depends on sample, control variables and identification of shocks. A number of studies report a multiplier of larger than one for the US (see, for example, Blanchard and Perotti 2002; Gali et al. 2007; Fatas and Mihov 2001). Burriel et al. (2010) argue that the size of the multiplier in general increases when controlling for the debt-to-GDP ratio, but it decreases for EU countries when controlling for financial stress. In addition, estimated multipliers are downward biased if financial variables are omitted (Gechert and Mentges, 2018).

Compared to VAR studies, NK-DSGE model-based studies impose more theoretically motivated restrictions on the system. These restrictions include the existence of Ricardian consumers and the central bank following a Taylor rule. Forni et al. (2009) utilize a NKDSGE model for Euro Area for the period 1980-2005 and report that government consumption expenditures have a mild Keynesian effect on output. Ratto et al. (2009) study the impact of government spending shocks on output in the Euro Area for the period of 1981 to 2006 and find that government consumption, investment and transfer shocks crowd-out 
private investment and private consumption of Ricardian consumers. In general, NK-DSGE models typically yield a small or negative impact of government spending on output due to the assumption of Ricardian households and monetary policy following a Taylor-rule.

The estimation of the regime-dependent multipliers, similar to linear estimation, can be categorized into three groups based on the estimation strategy. NK-DSGE models can have a nonlinear fiscal multiplier for several reasons. Fiscal multipliers in recessions can be large because of frictions due to asymmetric information between borrower and lender (Fernandez-Villaverde, 2010), because of binding finance constraints (Eggertsson and Krugman, 2012), the presence of those households whose borrowing is constrained by the value of their collateral (Turini et al., 2012), a depressed labour market (Michaillat, 2012). Most prominently, Eggertsson (2009), Woodford (2011) and Christiano et al (2011) demonstrate that when monetary policy hits the ZLB, the multiplier can be substantially larger than otherwise.

These theoretical arguments are supported by several empirical investigations. Using regime-switching VAR approaches, Auerbach and Gorodnichenko (2012a) and Bachmann and Sims (2012) find a multiplier of much larger than one during downswings. Auerbach and Gorodnichenko (2012b) study OECD countries for the period of 1985-2010 and report a multiplier of 2.3 for the US in downswing compared to zero in upswings. De Cos and MoralBenito (2013) report a multiplier of 1.4 during downswing vs. 0.6 during upswing for Spain during 1986-2012. In a similar vein, Thomakos (2012) finds a multiplier of 1.32 in downswing compared to zero during tranquil periods for Greece for the period 2000-2012. In opposition to the former studies, Ramey and Zubairy (2013) investigate nonlinearity for periods of high unemployment (i.e. average unemployment above 6.5 percent) and ZLB in the US and claim that multipliers are by and large linear. 
Other studies have used TSLS estimations methods to measure the size of multiplier during the crisis and normal times. For example, Turini et al. (2012) study 56 countries and estimate multipliers for the period of banking crisis vs. normal times. They report a multiplier of 0.8 during crisis and 0.2 in normal times. Afonso et al (2010) study 98 countries using TSLS estimation for the period of 1981-2007 and find a multiplier within a range of 0.6 to 1.1. When they investigate nonlinearity between the periods of crisis vs. normal times, they find that multipliers are not statistically different among different regimes.

In a more recent paper, Qazizada and Stockhammer (2015) investigate nonlinear multipliers for the periods of downswing vs. upswing for 21 advanced countries over the period of 1979-2011. To overcome endogeneity of government spending, they employ TSLS estimation and use one year lagged value of government consumption as an instrument for government spending. They find a government consumption multiplier of 3.07 in the downswing vs. 1.01 in an upswing.

Gechert and Rannenberg (2014) conduct a meta-regression analysis of estimates of fiscal multipliers, based a dataset with 1882 observations from 98 econometric studies, such as the ones listed above. The exploited studies were published between 1993 and 2013. They identify multipliers for several components of government spending and income: unspecified (overall) government spending, final consumption spending, investment, and military spending. They also report multipliers for government transfers and taxes. To analyse multipliers for different phases of the business cycle, they distinguish between regimeindependent multiplier estimates as well as a lower (downswing) regime, and an upper (upswing) regime. According to the meta-estimates, spending multipliers increase by 0.6 to 0.8 units during downswings as compared to an average scenario. For government consumption in particular, the multiplier is approximately 1.8 in a downswing compared to 0.50 and 0.54 during the upswing and average scenario respectively. 


\section{Calculating growth contributions of fiscal policy}

In this paper, we seek to answer what has been the contribution of fiscal policy to GDP growth in seven European countries and the United States during and after the Great Recession. To accomplish this, we first identify the turning points for the business cycle for the period of 2007 to 2014, for each country. Then, we calculate the impact of fiscal policy by multiplying the changes in fiscal policy with the respective multiplier in those periods. For multipliers, we use the results from Qazizada and Stockhammer (2015) (QS henceforth) and Gechert and Rannenberg (2014) (GS henceforth) complementarily in order to cope with econometric model uncertainty. QS report a multiplier for government consumption; this is frequently used as a summary measure for fiscal policy, but to the extent that other fiscal components and tax income develop differently from government consumption, it may give misleading results. In contrast, GS report multipliers for different categories of government consumption (GCON), government investment (GINV), government transfers (GTRAN), and taxes (GTAX). They control for import share of GDP and thus have country-specific multipliers. A high level of import share means a greater leakage from the economy and thus a lower size of the multiplier. Table 1 presents the average multipliers for our countries. While regime-independent multipliers with the exception of GINV are below one and multipliers in upswing are all smaller than unity, downswing multipliers (with the exception of GTAX) are all above one. The largest one is GTRAN with a size of more than 2.78 for the US.

Insert Table 1 about here 
For our calculations of the growth contribution of fiscal policy, we use both the estimates from QS and GS. The QS multipliers are assumed identical in all countries. To calculate the growth contribution of fiscal policy, GCFP, we use an estimate of the multiplier $(\widehat{m})$ and multiply it with the actual change in the stance of fiscal policy in order to get a size effect of fiscal policy

$$
G C F P_{j}^{Q S}=\widehat{m}^{Q S} \Delta G C O N_{j}
$$

In order to calculate the total fiscal impact based on GR, we cumulate the effects for government consumption, government investment, taxes, and transfers. ${ }^{3}$ For this we need to make a set of adjustments. While the government expenditure data can be used directly, the government income variables need to take into account income induced by the governments' own expenditures. The tax and transfer multipliers apply to the tax and transfer impulses, but some of the actual tax incomes are induced by the governments' expenditures causing more tax income. The observed tax and transfer income thus needs to be adjusted. We define tax and transfers impulses as follows:

$$
\begin{aligned}
\Delta T X^{\text {impulse }}= & {\left[\Delta T X-\varepsilon^{T X, Y} \widehat{m}^{G C O N}\left(\frac{T X}{Y}\right) \Delta G C O N-\varepsilon^{T X, Y} \widehat{m}^{G I N V}\left(\frac{T X}{Y}\right) \Delta G I N V\right.} \\
& \left.-\varepsilon^{T X, Y} \widehat{m}^{T R}\left(\frac{T X}{Y}\right) T R^{i m p u l s e}\right] \frac{1}{1-\varepsilon^{T X, Y} \widehat{m}^{T X}\left(\frac{T X}{Y}\right)} \\
\Delta T R^{\text {impulse }}= & {\left[\Delta T R-\varepsilon^{T R, Y} \widehat{m}^{G C O N}\left(\frac{T R}{Y}\right) \Delta G C O N-\varepsilon^{T R, Y} \widehat{m}^{G I N V}\left(\frac{T R}{Y}\right) \Delta G I N V\right.} \\
& \left.-\varepsilon^{T R, Y} \widehat{m}^{T X}\left(\frac{T R}{Y}\right) T X^{i m p u l s e}\right] \frac{1}{1-\varepsilon^{T R, Y} \widehat{m}^{T R}\left(\frac{T R}{Y}\right)}
\end{aligned}
$$

\footnotetext{
${ }^{3}$ The government consumption multipliers by Qazizada and Stockhammer (2015) and those by Gechert and Rannenberg (2014) do not have the same interpretation. Qazizada and Stockhammer use government consumption as summary variable for all government expenditures. It should thus pick up other components of government expenditures and tax as far as they are correlated. In Gechert and Rannenberg, the government consumption multipliers are conditional on the other fiscal components and thus only measure partial effects.
} 
These equations essentially state that the tax impulse, $T X^{\text {impulse }}$, is the observed tax, $T X$, income minus the tax income induced by government expenditures times, e.g. GCON, the respective multiplier, $m^{G C O N}$, and the income elasticity of taxes, $\varepsilon^{T X, Y}$. We assume, for simplicity, that those elasticities are equal to unity, which is a crude but plausible approximation (Price et al. 2014). While the transformations may look substantial, it turns out that their effect on the results is rather small.

The total growth contribution of fiscal policy is then defined as:

$G C F P^{G R}=\widehat{m}^{G C O N} \Delta G C O N+\widehat{m}^{G I N V} \Delta G I N V+\widehat{m}^{T X} \Delta T X^{\text {impulse }}+\widehat{m}^{T R} T R^{\text {impulse }}$

This exercise is similar to, but not strictly, an out of sample forecast, because we perform our calculations for a period (2007-2014) that is mostly outside of the sample used for the estimation of the multipliers. For the QS fiscal effects there is some overlap in the samples and the second half of the forecast period is strictly out-of-sample; the GR multipliers, stemming from 98 studies use samples ranging from the 1890s to 2012, but with the lion's share of the information set stemming from pre-crisis data.

We have experimented with several ways of measuring downswings and we use an unemployment-based measure as our preferred method. We use the quarterly unemployment rate as a measure of the business cycle to discern the business cycle turning points. We define a downswing as three or more consecutive quarters of uni-directional change with a minimum cumulative change of one percentage point in unemployment. ${ }^{4}$ Otherwise quarters are classified as upswings.

Alternatively, we could use the OECD Composite Leading Index (OECD CLI). That is a widely applied measure to distinguish upswings and downswings; however, in our

\footnotetext{
${ }^{4}$ This way of delineating business cycles builds on Ball $(1994,1999)$.
} 
sample, the indicator often is at odds with the GDP growth rate of respective countries. For instance, in 2009, Germany, Italy, and Portugal had negative GDP growth rates, but according to OECD CLI, 2009 is defined a period of expansion for these countries. Likewise, Spain in 2012 and Greece in 2012 and 2013 had negative growth rates, but those periods are expansions according to OECD CLI. Due to these counterintuitive effects, we prefer the simple change in unemployment measure to identify upswings and downswings. A second alternative measure is the output gap. This relies on an estimate of the NAIRU, the nonaccelerating inflation rate of unemployment. Importantly, the data are only available at an annual basis. Using the output gap measure does give qualitatively similar results to the ones reported below (available upon request).

We identify up and downswings with quarterly data, but our fiscal variables are annual data. We calculate annual multipliers as the average of the four quarterly regimes. For instance, if there are three quarters of the downswing and one quarter of upswing in one year, the annual weighted average multiplier based on QS will be $(3.07 * 0.75+1.01 * 0.25)=2.56$ for

instance. For comparison, we also present the contribution of fiscal policy under the assumption of non-regime multipliers, assuming that multipliers are linear across different regimes.

The source of our data for unemployment is OECD. All our other data are obtained from the AMECO database.

\section{The growth contributions of fiscal policy since the crisis}

Figure 1 plots the overall impact of fiscal policy on GDP based on the QS and GR multipliers for Germany, the UK, the USA, Greece, Ireland, Italy, Portugal, and Spain. We 
report both the impacts on GR regime-dependent multipliers and GR non-regime multipliers (GR-NR). For most countries except Ireland, the QS and GR-based fiscal effects look rather similar and differ in a qualitatively similar vein from the regime-independent impacts.

Insert Figure 1 about here

While Germany had positive growth contributions of fiscal policy throughout the period (except for GR non-regime measures for 2014), effects were larger in 2008 and 2009 than thereafter (Figure 1.1). The growth contributions overall, however, are modest. At the peak, fiscal effects were below 1.5\% of GDP (both according to the GR and the QS measure) and consistently below .5\% after 2009. For the UK, we find positive and substantial growth contributions until 2010 with both the QS and GR measure (Figure 1.2). The GR fiscal effect is at 4.5\% of GDP for 2009 substantially larger than the QS measure (just below 2\%), but otherwise they are rather similar. The UK had modest negative growth contributions of fiscal policy 2010 and 2011 (of up to 1\% of GDP) and a neutral stance thereafter. The US's positive fiscal effects in 2008 and 2009 are much higher for the GR measure (7\% in 2009) than with the QS measure (1\%, 2009) (Figure 1.3). After 2010, the QS method shows marginally negative growth contributions and GR shows modest negative effects (around -1\%). For all three countries the non-regime multipliers depict very small growth contributions, which never exceed the $-1 \%$ to $+1 \%$ of GDP band.

For Greece, the growth contributions of fiscal policy were sizable and expansionary in 2009, with 3\% of GDP according to GR multipliers and 4\% according to QS multipliers (Figure 1.4). From 2010 fiscal effects were negative and large: around -7\% in 2010, which 
fell to $-4 \%$ in 2013. Only in 2014 was there a neutral fiscal policy effect. QS and GR fiscal effects are very similar. GR non-regime fiscal effects give similar time profile, but are substantially smaller.

For Ireland, the QS multipliers imply expansionary effects in 2008, that fall sharply thereafter. In 2010, the QS growth contributions of fiscal policy amount to $-4 \%$ of GDP (Figure 1.5). Thereafter values are below $-2 \%$, but remain negative until 2014. Ireland is the one country where the QS and GR multipliers differ substantially. GR multipliers for Ireland are negative, which is because of Ireland's high import shares. This either means that Ireland has consistently negative multipliers or that this result is an artefact of the estimation method. $^{5}$

For Italy GR and QS indicate small positive growth contributions until 2010 and then sizable negative impacts (Figure 1.6). Only for 2009 do the GR fiscal effects exceed 2\% of GDP. For Portugal we find positive growth contributions with the GR measure until 2010 (Figure 1.7). According to the GR multipliers, there was already a small negative fiscal effect in 2010. Overall, the GR and QS measures do give a similar picture for Portugal, though values are somewhat higher with the QS measure. For Spain, we find positive fiscal effects until 2010 with both measures and negative impacts thereafter (Figure 1.8). GR impacts are larger than QS impacts, in particular for 2009, where GR indicate a growth contribution of fiscal policy of 7\%, but QS only 3\% (non-regime GR impacts are 0.5\%). The time profile looks similar with all three measures.

\footnotetext{
${ }^{5}$ While Ireland is often cited as case for EFC, recent studies report substantial positive multipliers for the Irish economy (Barrell et al 2013, Bergin et al 2013). There is an additional issue about the reliability of Irish GDP data because of the role of multinationals for the Irish economy and the fact that Irish tax policy encourages firms to locate headquarters in Ireland. In 2015 Irish GDP was reported to have risen by 26.3\%, which was mainly due to intellectual property rights (OECD 2016). Our simulations end in 2014 and thus do not include this conspicuous year.
} 
Overall GR and QS growth contributions of fiscal policy show a similar picture, with the exception of Ireland, were GR gives negative multipliers due to Ireland's high import shares. GR impacts are larger than QS in most countries, most notably for 2008 and 2009. The QS measure is typically between the regime-dependent GR and non-regime GR. Overall government consumption seems to be a reasonably good proxy for overall fiscal policy.

In all countries, we observe a policy change between 2008-09 and 2010-14 (see Table 2). While the policy was clearly expansionary for all countries in the first phase, it shifted to restrictive or neutral in the second period. The extent to which this has happened differs substantially between the GIIPS and Germany, UK and USA. While policy shifted from expansionary to neutral, i.e. withdrawing the stimulus in Germany, UK and USA, policy in the GIIPS took a much more contractionary turn.

Insert Table 2

With the exception of Ireland, which gives somewhat mixed and inconclusive results, the general pattern arises that those countries that turned to a restrictive fiscal stance after 2010 faced a double-dip recession. Those countries that embarked on a neutral or slightly expansionary fiscal stance experienced a recovery. Both patterns very much support a Keynesian story of a significant positive impact of fiscal policy on growth. One might argue that the crisis countries simply did not have the fiscal leeway for a neutral fiscal stance and had to embark on austerity without any realistic alternative, thus claiming a reverse-causality narrative from low growth to fiscal tightening. However, the bad growth performance in 
those countries is still at odds with the expansionary fiscal contraction hypothesis that forecasted a strong recovery for austere countries.

To assess the size of the effect of fiscal policy relative to a country's actual GDP decline, we need to know its deviation from trend output. We calculate the pre-crisis trend growth for the 1998-2008 period (see Table 2). We then calculate the gap between actual GDP and potential GDP if growth had continued at pre-crisis trends. For 2001-14 we see a large gap for GIIPS countries and a modest one for UK and USA. Only for Germany did growth exceed pre-crisis trends. How much of this gap is explained by fiscal policy? For Greece between half (according to the GR multipliers) and one third of the deviation from pre-crisis trend growth in the $2010-14$ period is explained by fiscal contraction. For Portugal about half of the gap is due to fiscal policy; for Italy between one fifth (with GR multipliers) and one third (with QS multipliers) and for Spain between one eighth (according to QS multipliers) and one third (with GR multipliers). Overall this suggests that the poor economic growth performance in the GIIPS countries since 2010 has to a significant extent been caused by tightening fiscal policy.

\section{Conclusions}

The paper has calculated the effect of fiscal policy in eight OECD economics since 2008, based on the regime-dependent multipliers reported by Qazizada and Stockhammer (2015) and Gechert and Rannenberg (2014) for the GIIPS countries, Germany, the USA and the UK. For most countries QS and GR growth contributions of fiscal policy are similar, with GR impact typically showing larger effects. All countries pursued expansionary fiscal policy during the 2008/09 recession and all of them switched to a tighter stance from 2010 onwards. However, the extent of fiscal tightening has differed substantially across countries. While 
austerity meant essentially a shift from expansionary to neutral for Germany, the USA and the UK, the fiscal contraction was much stronger in the GIIPS countries. As compared to the former group, the GIPS countries (with the exception of Ireland) experienced a substantial decline in output 2010-14 and fiscal policy explains about half of this decline for Greece, Portugal, Spain and Italy. We thus conclude that fiscal policy played a major role in the depression that southern European countries have faced.

\section{References}

Afonso, A. (2006), 'Expansionary fiscal consolidations in Europe: new evidence’, ECB Working Paper No. 675

Afonso, A., Gruner, H. and Kolerus, C. (2010), 'Fiscal policy and growth: do financial crises make a difference?', ECB Working Paper No. 1217

Alesina, A. and Perotti, R. (1995) 'Fiscal expansions and fiscal adjustments in OECD countries', Economic Policy, 10 (21), pp.205-248

Arestis, P. (1992), The Post-Keynesian Approach to Economics: An Alternative Analysis of Economic Theory and Policy, Cheltenham: Edward Elgar

Arestis, P, 2009. New Consensus Macroeconomics: A critical appraisal. Levy Institute Working Papers 564

Arestis, P. and Sawyer, M. (1998), 'Keynesian economic policies for the new millenium' Economic Journal, 108, 181-95

Auerbach, A. and Gorodnichenko, Y. (2012a), Measuring the Output Responses to Fiscal Policy. American Economic Journal: Economic Policy, 4(2). S. 1-27.

Auerbach, A, and Gorodnichenko, Y., (2012b) 'Fiscal Multipliers in Recession and Expansion', in Fiscal Policy after the Financial Crisis, edited by Alberto Alesina and Francesco Giavazzi (Chicago: University of Chicago Press).

Bachmann, R. and Sims, E. (2012) 'Confidence and the transmission of government spending shocks', Journal of Monetary Economics, 59, pp.235-249

Ball, Laurence, 1994. Disinflation and the NAIRU. In: C. Romer and D. Romer (eds.): Reducing Inflation. Motivation and Strategy. Chicago: University of Chicago Press

Ball, Laurence, 1999. Aggregate demand and long-run unemployment. Brooking Papers on Economic Activity 2, 1999: 189-236

Barrell, R, Holland, D, Hurst, I, 2013. Fiscal multipliers and prospects for consolidation. OECD Journal: Economic Studies 3, 1: 71-102

Barro, R (1989) 'The Ricardian approach to budget deficit', The Journal of Economic Perspectives, 3 (2), pp. 37-54

Bergin, A, Conefrey, T, FitzGerald, J, Kearney, I, Žnuderl, N, 2013. The HERMES-13 macroeconomic model of the Irish economy. ESRI Working Paper 460

Blanchard, O. and Leigh, D. (2013), 'Growth Forecast Errors and Fiscal Multipliers', International Monetary Fund Working Paper WP13/1

Blanchard, O. and Perotti, R. (2002) 'An empirical characterization of the dynamic effects of changes in government spending and taxes on output', The Quarterly Journal of Economics, 117 (4), pp. 1329-1368. 
Blanchard, O., Dell'Ariccia, G., Mauro, P., 2010. Rethinking macroeconomic policy. IMF Staff Position Note $10 / 03$

Burriel, P., de Castro, F., Garrote, D., Gordo, E., Paredes, J. and Perez, J. J. (2010) 'Fiscal policy shocks in the euro area and the US: an empirical assessment', Fiscal Studies, 31 (2), pp. 251285.

Christiano, L, Eichenbaum, M, \& Rebelo, S (2011), 'When Is the Government Spending Multiplier Large?', Journal Of Political Economy, 119 (1), pp. 78-121

Coy, Peter (2010) Keynes vs. Alesina. Alesina Who? http://www.bloomberg.com/bw/stories/2010-0629/keynes-vs-dot-alesina-dot-alesina-who [accessed 5/1/2014]

De Cos, P. and Moral-Benito, E. (2013), 'Fiscal Multipliers in Turbulent Times: The Case of Spain', Banco de Espana Working Paper No. 1309.

Dullien, S. (2012), 'Is new always better than old? On the treatment of fiscal policy in Keynesian models', Review of Keynesian Economics, Inaugural Issue, pp. 5-23

Eggertsson, G. and Krugman, P. (2012), 'Debt, deleveraging, and the liquidity trap: a Fisher-MinskyKoo approach', Quarterly Journal of Economics, 127 (3), pp.1469-1513

Eggertsson, G. B. (2009) 'What fiscal policy is effective at zero interest rate?, FRB of New York Staff Report No. 402.

Fatas, A. and Mihov, I. (2001), 'The effects of fiscal policy on consumption and employment: theory and evidence', CEPR Discussion Paper No. 2760 London: Center for Economic Policy Research.

Fernández-Villaverde, J. (2010) 'Fiscal policy in a model with financial frictions', American Economic Review, 100 (2), pp.35-40.

Forni, L., Monteforte, L. and Sessa, L. (2009) 'The general equilibrium effects of fiscal policy: estimates for the Euro Area', Journal of Public Economics, 93, pp. 559-585

Friedman, M. (1957), A theory of the consumption function. Princeton, NJ: Princeton University Press.

Friedman, M. (1968), 'The role of monetary policy', The American Economic Review, 58 (1), pp. 1-17

Gali, J., Lopez-Salido, J. D. and Valles, J. (2007), 'Understanding the effects of government spending on consumption', Journal of the European Economic Association, 5 (1), pp. 227-270.

Gechert, S., Hughes Hallett, A., Rannenberg, A. (2016), Fiscal multipliers in downturns and the effects of Eurozone consolidation, Applied Economics Letters 23(16), 1138-1140.

Gechert, S. (2015), 'What fiscal policy is most effective? A meta-regression analysis', Oxford Economic Papers, 67 (3), pp.553-580

Gechert, S. and Mentges, R. (2018), Financial Cycles and Fiscal Multipliers, Applied Economics (early online) http://www.tandfonline.com/eprint/IW2qFEp6ZhASvewrQe5i/full

Gechert, S. and Rannenberg, A. (2014) 'Are fiscal multipliers regime-dependent? A meta regression analysis', IMK Working Paper 139-2014

Gechert, S. and Will, H. (2012) 'Fiscal Multipliers: A Meta Regression Analysis', IMK Working Paper 97-2012, IMK at the Hans Boeckler Foundation, Macroeconomic Policy Institute.

Giavazzi, F. and Pagano, M. (1990), 'Can Severe Fiscal Contractions Be Expansionary? Tales of Two Small European Countries', NBER Macroeconomics Annual 5: 75-111

Giavazzi, F. and Pagano, M. (1997), 'Non-Keynesian Effects of Fiscal Policy Changes: International Evidence and the Swedish Experience', Swedish Economic Policy Review, 3 (1), pp. 67-103

Greenwald, B. and Stiglitz, J. (1987) 'New Keynesian and new classical economics', Oxford Economic Papers, 39 (1), pp. 119-133

Hall, P, 1989. The political power of economic ideas. Keynesianism across nations. Princeton: Princeton University Press

Hebous, S. (2011), 'The Effects of Discretionary Fiscal Policy on Macroeconomic Aggregates: A Reappraisal', Journal of Economic Surveys, 25 (4), pp.674-707

Herndon, T. / Ash, M. / Pollin, R. (2013), Does High Public Debt Consistently Stifle Economic Growth? A Critique of Reinhart and Rogoff. PERI Working Paper, Nr. 322.

Ilzetzki, E., Mendoza, E. G. and Vegh, C. A. (2013) 'How big (small?) are fiscal multipliers?', Journal of Monetary Economics, 60 (2), pp. 239-254.

Krugman, P. (2010), Myths of austerity. New York Times, 2 July 2010 
Laidler, D. (1986) 'The new-classical contribution to macroeconomics', Banca Nazionale Del Lavaoro Quarterly Review, (1986), 39 (156) pp.27-55

Lavoie, M, 2014. Post Keynesian economics. New Foundations. Aldershot: Edward Elgar

Mankiw, G. (2000) 'The savers-spenders theory of fiscal policy', NBER Working Paper No. 7571

Michaillat, P. (2012) 'Fiscal multipliers over the business cycle', Centre for Economic Performance, LSE, CEP Discussion Papers No. 8610

OECD (2016). Irish GDP up by 26.3\% in 2015? https://www.oecd.org/std/na/Irish-GDP-up-in-2015OECD.pdf (accessed 3/8/2017)

Palley, T. (1996), Post Keynesian Economics: Debt, Distribution and the Macro Economy, London: Macmillan

Price, R. / Dang, T.-T. / Guillemette, Y. (2014), New Tax and Expenditure Elasticity Estimates for EU Budget Surveillance. OECD Economics Department Working Papers, Nr. 1174.

Qazizada, W. and Stockhammer, E. (2015), Government spending multipliers in contraction and expansion, International Review of Applied Economics, 29 (2), pp.238-258

Ramey, V. A. and Zubairy, S. (2013) 'Government spending multipliers in good times and in bad: evidence from US historical data', mimeo

Rannenberg, A., Schoder, C. and Strasky, J. (2015), "The macroeconomic effects of the euro area's fiscal consolidation 2011-2013: A simulation-based approach”, Research Technical Paper 03/RT/2015, Central Bank of Ireland.

Ratto, M., Roeger, W. and Veld, J. (2009) 'QUEST III: An estimated open-economy DSGE model of the euro area with fiscal and monetary policy', Economic Modelling, 26 (1), pp. 222-233.

Reinhart, C. M. / Rogoff, K. S. (2010), Growth in a Time of Debt. American Economic Review, 100(2). S. 573-578.

Setterfield, M. (1993), 'Towards a Long-Run Theory of Effective Demand: Modeling Macroeconomic Systems with Hysteresis', Journal of Post Keynesian Economics, 15(3), pages 347-364,

Spilimbergo, A. Symansky S. and Schindler M. (2009), Fiscal Multipliers. IMF Staff Position Note SPN/09/11.

Stockhammer, E., (2008), Is the NAIRU a Monetarist, New Keynesian, Post Keynesian or Marxist theory? Metroeconomica 59 (4), 479-510

Stockhammer, E (2011), Wage norms, capital accumulation and unemployment. A Post Keynesian view. Oxford Review of Economic Policy 27, 2: 295-311

Summers, L. (2014), 'U.S. economic prospects: secular stagnation, hysteresis and the Zero Lower Bound', Business Economics, 49(2), pp. 65-73

Thomakos, D. (2012) 'Fiscal multipliers in deep economic recessions and the case for a 2-year extension in Greece's austerity programme', Eurobank EFG Economic Research, 8 (4), pp. 144

Woodford, M. (2011), 'Simple Analytics of the Government Expenditure Multiplier', American Economic Journal Macroeconomics, 3(1), pp.1-35. 

(2015)

Table 1: Multipliers for Different Types of Government Spending from Gechert and Rannenberg (2015) and Qazizada and Stockhammer

\begin{tabular}{|c|c|c|c|c|c|c|c|c|c|c|c|c|c|c|c|}
\hline \multicolumn{6}{|c|}{ Regime-dependent Multipliers: Downswing } & \multicolumn{5}{|c|}{ Regime-dependent Multipliers: Upswing } & \multicolumn{5}{|c|}{ Regime-independent Multipliers } \\
\hline Country & GCON & GINV & GTAX & GTRAN & $\begin{array}{c}\text { QS } \\
\text { Multiplier }\end{array}$ & GCON & GINV & GTAX & GTRAN & $\begin{array}{c}\text { QS } \\
\text { Multiplier }\end{array}$ & GCON & GINV & GTAX & GTRAN & $\begin{array}{c}\text { QS } \\
\text { Multiplier }\end{array}$ \\
\hline Germany & 1.48 & 1.58 & 0.09 & 2.25 & 3.07 & 0.19 & -0.04 & 0.04 & 0.05 & 1.01 & 0.23 & 1.18 & 0.06 & 0.1 & 1.7 \\
\hline UK & 1.59 & 1.69 & 0.19 & 2.36 & 3.07 & 0.29 & 0.07 & 0.14 & 0.16 & 1.01 & 0.34 & 1.28 & 0.17 & 0.21 & 1.7 \\
\hline USA & 2.01 & 2.11 & 0.61 & 2.78 & 3.07 & 0.71 & 0.49 & 0.56 & 0.58 & 1.01 & 0.76 & 1.71 & 0.59 & 0.63 & 1.7 \\
\hline Greece & 0.23 & 0.33 & -1.16 & 1 & 3.07 & 0.25 & 0.03 & 0.1 & 0.12 & 1.01 & 0.3 & 1.24 & 0.13 & 0.17 & 1.7 \\
\hline Ireland & 1.55 & 1.65 & 0.15 & 2.32 & 3.07 & -1.06 & -1.29 & -1.21 & -1.2 & 1.01 & -1.02 & -0.07 & -1.19 & -1.15 & 1.7 \\
\hline Italy & 1.67 & 1.77 & 0.27 & 2.43 & 3.07 & 0.43 & 0.21 & 0.28 & 0.3 & 1.01 & 0.48 & 1.42 & 0.31 & 0.35 & 1.7 \\
\hline Spain & 1.44 & 1.54 & 0.05 & 2.21 & 3.07 & 0.37 & 0.15 & 0.22 & 0.24 & 1.01 & 0.41 & 1.36 & 0.25 & 0.29 & 1.7 \\
\hline Portugal & 1.73 & 1.83 & 0.33 & 2.5 & 3.07 & 0.15 & -0.08 & -0.01 & 0.01 & 1.01 & 0.19 & 1.14 & 0.02 & 0.06 & 1.7 \\
\hline
\end{tabular}

Note: GCON=Government consumption Spending, GINV= Government investment, GTAX=Taxes, and GTRAN=Government Transfers Spending. GCON, GINV, GTAX and GTRAN are from Gechert and Rannenberg (2015). QS Multipliers refer to multiplier estimates from Qazizada and Stockhammer (2015). 
Figure 1: Annual Effect of Fiscal Policy on GDP Growth for 2007-2014

\subsection{Germany}

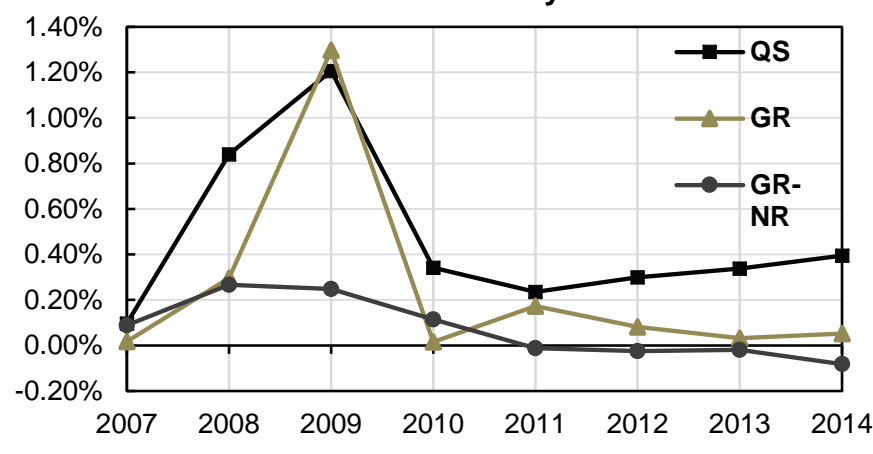

1.3 United States
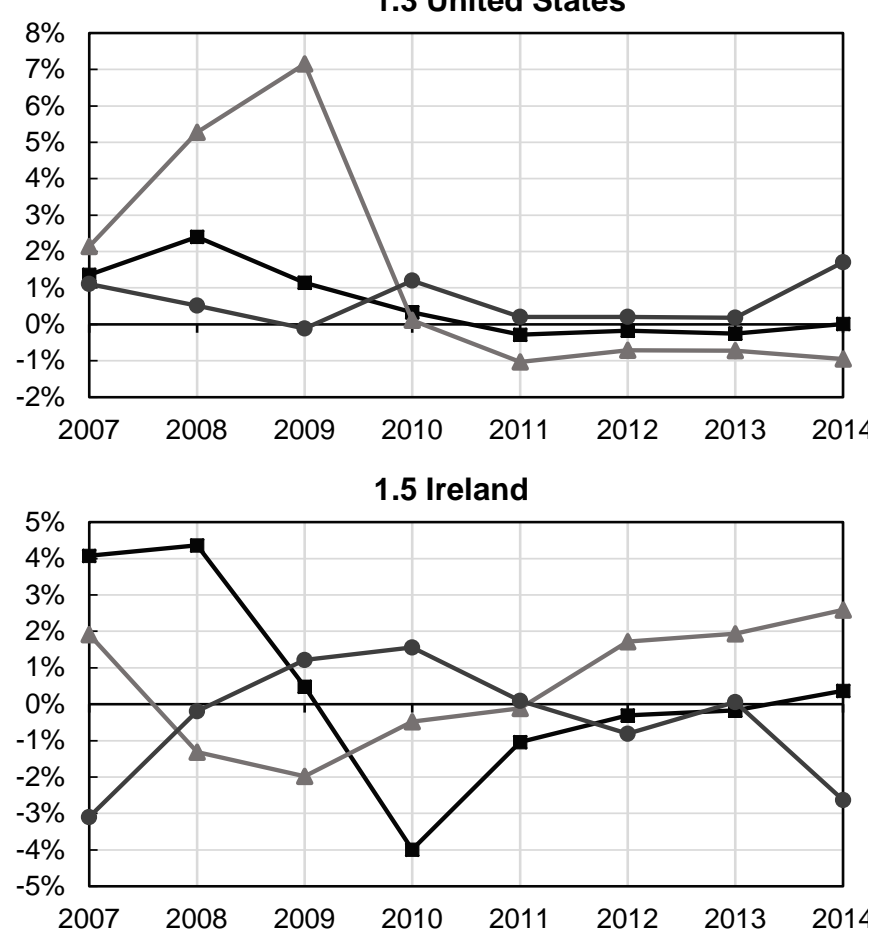

1.7 Portugal

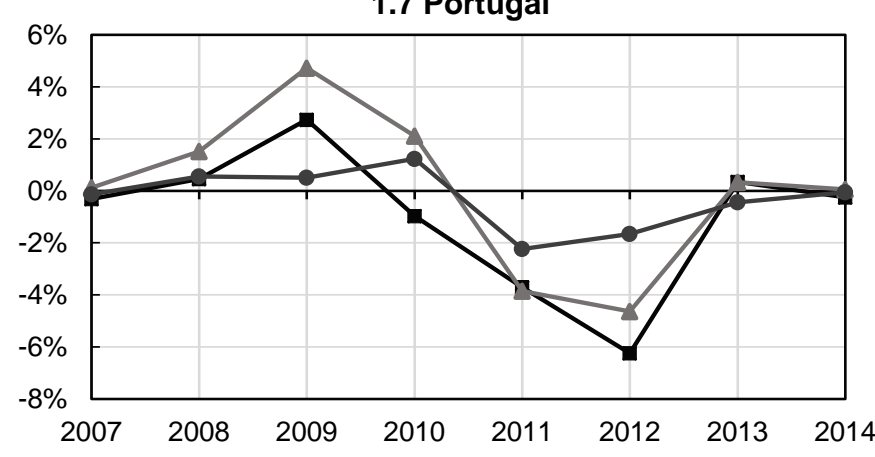

1.2 United Kingdom
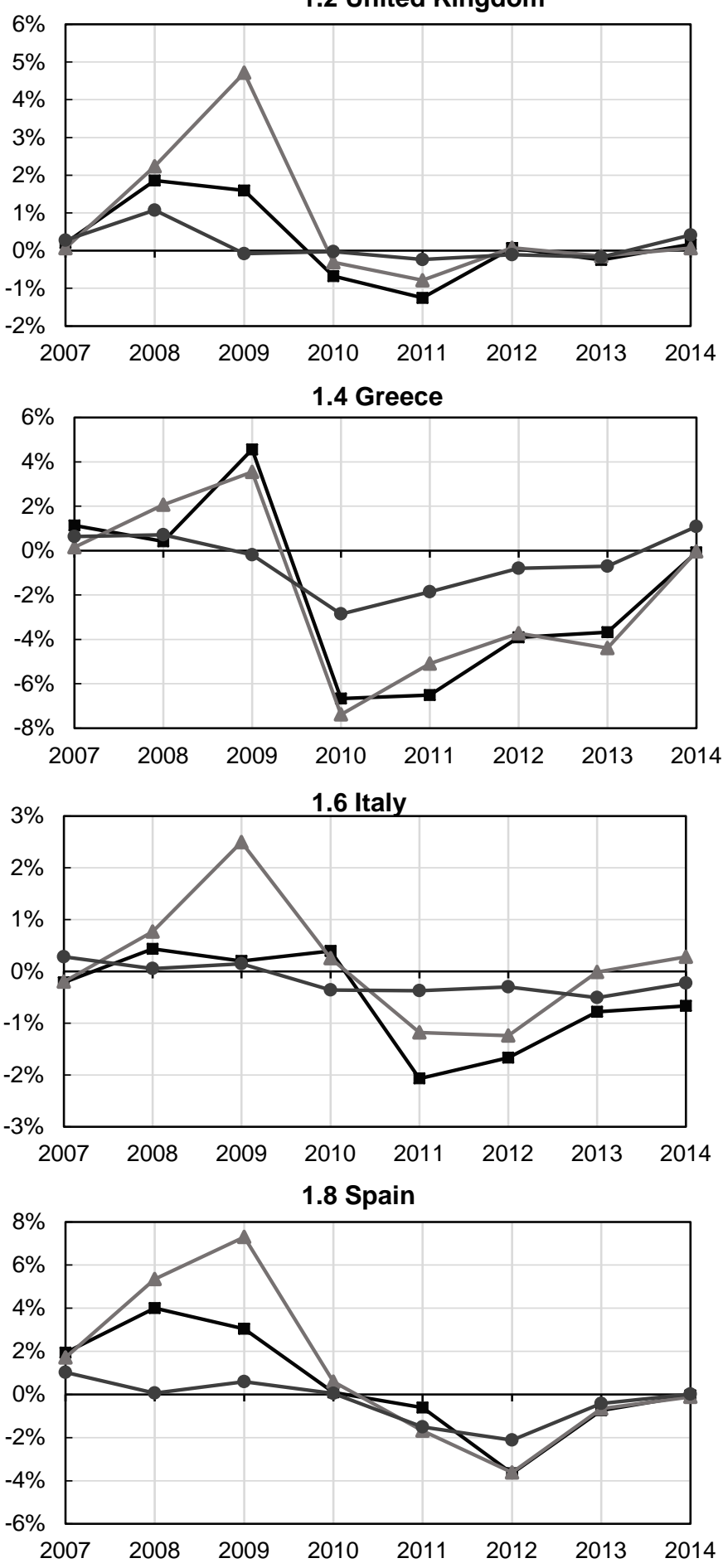

Note: QS refers to calculations using Qazizada and Stockhammer (2015) multipliers, GR refers to calculations based on Gechert and Rannenberg (2014) multipliers, and GR-NR refers to calculations using GR's non-regime dependent multipliers. 
Table 2: Cumulative Effect of Fiscal Policy Using GR and QS Multipliers

\begin{tabular}{|c|c|c|c|c|c|c|c|c|}
\hline \multicolumn{9}{|c|}{ Impact of Fiscal Policy with GR Multipliers } \\
\hline & Germany & UK & USA & Greece & Ireland & Italy & Portugal & Spain \\
\hline 2008/09 & $1.60 \%$ & $6.90 \%$ & $12.40 \%$ & $5.60 \%$ & $-3.30 \%$ & $3.30 \%$ & $6.20 \%$ & $12.70 \%$ \\
\hline 2010/14 & $0.40 \%$ & $-1.10 \%$ & $-3.30 \%$ & $-20.60 \%$ & $5.70 \%$ & $-1.90 \%$ & $-6.00 \%$ & $-5.50 \%$ \\
\hline \multicolumn{9}{|c|}{ Impact of Fiscal Policy with QS Multipliers } \\
\hline & Germany & UK & USA & Greece & Ireland & Italy & Portugal & Spain \\
\hline 2008/09 & $1.10 \%$ & $2.00 \%$ & $2.10 \%$ & $2.90 \%$ & $2.80 \%$ & $0.40 \%$ & $1.90 \%$ & $4.10 \%$ \\
\hline 2010/14 & $0.80 \%$ & $-1.10 \%$ & $-0.20 \%$ & $-12.20 \%$ & $-3.00 \%$ & $-2.80 \%$ & $-6.30 \%$ & $-2.90 \%$ \\
\hline \multicolumn{9}{|c|}{ Actual GDP Growth } \\
\hline & Germany & UK & USA & Greece & Ireland & Italy & Portugal & Spain \\
\hline 2008/09 & $-2.40 \%$ & $-1.80 \%$ & $-1.00 \%$ & $-0.90 \%$ & $-1.60 \%$ & $-4.00 \%$ & $-0.50 \%$ & $0.10 \%$ \\
\hline 2010/14 & $9.80 \%$ & $8.70 \%$ & $11.10 \%$ & $-24.00 \%$ & $7.10 \%$ & $-2.60 \%$ & $-4.70 \%$ & $-2.50 \%$ \\
\hline \multicolumn{9}{|c|}{ average annual GDP Growth 1998-2008 } \\
\hline & Germany & UK & USA & Greece & Ireland & Italy & Portugal & Spain \\
\hline $1998 / 2008$ & $1.58 \%$ & $2.68 \%$ & $2.57 \%$ & $3.51 \%$ & $5.13 \%$ & $1.23 \%$ & $1.62 \%$ & $3.57 \%$ \\
\hline \multicolumn{9}{|c|}{ Gap Between Actual and Potential GDP } \\
\hline & Germany & UK & USA & Greece & Ireland & Italy & Portugal & Spain \\
\hline 2008/09 & $5.56 \%$ & $7.16 \%$ & $6.14 \%$ & $7.93 \%$ & $11.86 \%$ & $6.47 \%$ & $3.73 \%$ & $7.05 \%$ \\
\hline $2010 / 14$ & $-1.91 \%$ & $4.70 \%$ & $1.74 \%$ & $41.57 \%$ & $18.55 \%$ & $8.77 \%$ & $12.79 \%$ & $20.37 \%$ \\
\hline
\end{tabular}




\section{Appendix}

A 1: Annual Effect of Fiscal Policy Using GR Multipliers

\begin{tabular}{lllllllll}
\hline Year & Germany & UK & USA & Greece & Ireland & Italy & Portugal & Spain \\
\hline \hline 2007 & $0.02 \%$ & $0.06 \%$ & $2.14 \%$ & $0.15 \%$ & $1.91 \%$ & $-0.20 \%$ & $0.12 \%$ & $1.71 \%$ \\
2008 & $0.30 \%$ & $2.23 \%$ & $5.27 \%$ & $2.07 \%$ & $-1.31 \%$ & $0.77 \%$ & $1.52 \%$ & $5.35 \%$ \\
2009 & $1.30 \%$ & $4.71 \%$ & $7.15 \%$ & $3.55 \%$ & $-1.98 \%$ & $2.50 \%$ & $4.73 \%$ & $7.30 \%$ \\
2010 & $0.02 \%$ & $-0.31 \%$ & $0.12 \%$ & $-7.38 \%$ & $-0.48 \%$ & $0.25 \%$ & $2.11 \%$ & $0.59 \%$ \\
2011 & $0.17 \%$ & $-0.78 \%$ & $-1.03 \%$ & $-5.09 \%$ & $-0.11 \%$ & $-1.18 \%$ & $-3.85 \%$ & $-1.69 \%$ \\
2012 & $0.08 \%$ & $0.08 \%$ & $-0.72 \%$ & $-3.73 \%$ & $1.71 \%$ & $-1.24 \%$ & $-4.63 \%$ & $-3.62 \%$ \\
2013 & $0.03 \%$ & $-0.14 \%$ & $-0.72 \%$ & $-4.39 \%$ & $1.94 \%$ & $-0.01 \%$ & $0.33 \%$ & $-0.65 \%$ \\
2014 & $0.05 \%$ & $0.06 \%$ & $-0.95 \%$ & $-0.03 \%$ & $2.59 \%$ & $0.28 \%$ & $0.06 \%$ & $-0.11 \%$ \\
\hline
\end{tabular}

A 2: Cumulative Effect of Fiscal Policy Using GR Multipliers

\begin{tabular}{cllllllll}
\hline Year & Germany & UK & USA & Greece & Ireland & Italy & Portugal & Spain \\
\hline \hline 2007 & $0.02 \%$ & $0.06 \%$ & $2.14 \%$ & $0.15 \%$ & $1.91 \%$ & $-0.20 \%$ & $0.12 \%$ & $1.71 \%$ \\
2008 & $0.31 \%$ & $2.29 \%$ & $7.41 \%$ & $2.22 \%$ & $0.60 \%$ & $0.57 \%$ & $1.64 \%$ & $7.06 \%$ \\
2009 & $1.61 \%$ & $7.01 \%$ & $14.56 \%$ & $5.76 \%$ & $-1.38 \%$ & $3.06 \%$ & $6.37 \%$ & $14.36 \%$ \\
2010 & $1.63 \%$ & $6.70 \%$ & $14.68 \%$ & $-1.62 \%$ & $-1.86 \%$ & $3.32 \%$ & $8.47 \%$ & $14.96 \%$ \\
2011 & $1.80 \%$ & $5.92 \%$ & $13.64 \%$ & $-6.71 \%$ & $-1.96 \%$ & $2.14 \%$ & $4.62 \%$ & $13.26 \%$ \\
2012 & $1.88 \%$ & $6.00 \%$ & $12.93 \%$ & $-10.44 \%$ & $-0.25 \%$ & $0.90 \%$ & $-0.01 \%$ & $9.64 \%$ \\
2013 & $1.91 \%$ & $5.86 \%$ & $12.21 \%$ & $-14.83 \%$ & $1.69 \%$ & $0.89 \%$ & $0.32 \%$ & $8.99 \%$ \\
2014 & $1.97 \%$ & $5.92 \%$ & $11.26 \%$ & $-14.86 \%$ & $4.28 \%$ & $1.17 \%$ & $0.37 \%$ & $8.88 \%$ \\
\hline Year & Germany & UK & USA & Greece & Ireland & Italy & Portugal & Spain \\
\hline $2007 / 09$ & $1.61 \%$ & $7.01 \%$ & $14.56 \%$ & $5.76 \%$ & $-1.38 \%$ & $3.06 \%$ & $6.37 \%$ & $14.36 \%$ \\
$2010 / 14$ & $0.35 \%$ & $-1.09 \%$ & $-3.30 \%$ & $-20.62 \%$ & $5.66 \%$ & $-1.90 \%$ & $-5.99 \%$ & $-5.48 \%$ \\
\hline
\end{tabular}

A 3: Annual Effect of Fiscal Policy Using QS Multiplier

\begin{tabular}{rrrlrrrrr}
\hline Year & Germany & UK & US & Greece & Ireland & Italy & Portugal & Spain \\
\hline \hline 2007 & $0.10 \%$ & $0.20 \%$ & $1.36 \%$ & $1.14 \%$ & $4.08 \%$ & $-0.21 \%$ & $-0.30 \%$ & $1.94 \%$ \\
2008 & $0.84 \%$ & $1.86 \%$ & $2.40 \%$ & $0.42 \%$ & $4.36 \%$ & $0.44 \%$ & $0.46 \%$ & $4.00 \%$ \\
2009 & $1.21 \%$ & $1.60 \%$ & $1.15 \%$ & $4.56 \%$ & $0.48 \%$ & $0.20 \%$ & $2.74 \%$ & $3.05 \%$ \\
2010 & $0.34 \%$ & $-0.68 \%$ & $0.33 \%$ & $-6.66 \%$ & $-3.99 \%$ & $0.40 \%$ & $-0.97 \%$ & $0.09 \%$ \\
2011 & $0.24 \%$ & $-1.25 \%$ & $-0.28 \%$ & $-6.51 \%$ & $-1.04 \%$ & $-2.07 \%$ & $-3.71 \%$ & $-0.62 \%$ \\
2012 & $0.30 \%$ & $0.06 \%$ & $-0.17 \%$ & $-3.91 \%$ & $-0.31 \%$ & $-1.66 \%$ & $-6.24 \%$ & $-3.66 \%$ \\
2013 & $0.34 \%$ & $-0.25 \%$ & $-0.25 \%$ & $-3.67 \%$ & $-0.17 \%$ & $-0.78 \%$ & $0.35 \%$ & $-0.75 \%$ \\
2014 & $0.39 \%$ & $0.17 \%$ & $0.01 \%$ & $-0.08 \%$ & $0.37 \%$ & $-0.67 \%$ & $-0.24 \%$ & $-0.05 \%$ \\
\hline
\end{tabular}


A 4: Cumulative Effect of Fiscal Policy Using QS Multiplier

\begin{tabular}{lrrrrrrrr}
\hline Year & Germany & UK & US & Greece & Ireland & Italy & Portugal & Spain \\
\hline \hline 2007 & $0.10 \%$ & $0.20 \%$ & $1.36 \%$ & $1.14 \%$ & $4.08 \%$ & $-0.21 \%$ & $-0.30 \%$ & $1.94 \%$ \\
2008 & $0.94 \%$ & $2.06 \%$ & $3.76 \%$ & $1.56 \%$ & $8.44 \%$ & $0.23 \%$ & $0.15 \%$ & $5.94 \%$ \\
2009 & $2.14 \%$ & $3.66 \%$ & $4.91 \%$ & $6.12 \%$ & $8.92 \%$ & $0.42 \%$ & $2.89 \%$ & $8.99 \%$ \\
2010 & $2.48 \%$ & $2.98 \%$ & $5.24 \%$ & $-0.54 \%$ & $4.93 \%$ & $0.82 \%$ & $1.92 \%$ & $9.08 \%$ \\
2011 & $2.72 \%$ & $1.73 \%$ & $4.96 \%$ & $-7.05 \%$ & $3.89 \%$ & $-1.25 \%$ & $-1.78 \%$ & $8.46 \%$ \\
2012 & $3.02 \%$ & $1.79 \%$ & $4.79 \%$ & $-10.96 \%$ & $3.58 \%$ & $-2.91 \%$ & $-8.02 \%$ & $4.80 \%$ \\
2013 & $3.36 \%$ & $1.54 \%$ & $4.54 \%$ & $-14.63 \%$ & $3.41 \%$ & $-3.70 \%$ & $-7.67 \%$ & $4.06 \%$ \\
2014 & $3.75 \%$ & $1.71 \%$ & $4.55 \%$ & $-14.71 \%$ & $3.78 \%$ & $-4.36 \%$ & $-7.91 \%$ & $4.01 \%$ \\
\hline Year & Germany & UK & US & Greece & Ireland & Italy & Portugal & Spain \\
\hline $2007 / 09$ & $2.14 \%$ & $3.66 \%$ & $4.91 \%$ & $6.12 \%$ & $8.92 \%$ & $0.42 \%$ & $2.89 \%$ & $8.99 \%$ \\
$2010 / 14$ & $1.61 \%$ & $-1.95 \%$ & $-0.36 \%$ & $-20.83 \%$ & $-5.14 \%$ & $-4.78 \%$ & $-10.81 \%$ & $-4.98 \%$ \\
\hline
\end{tabular}

A 5: Actual GDP Growth

\begin{tabular}{lllllllll}
\hline Year & Germany & UK & USA & Greece & Ireland & Italy & Portugal & Spain \\
\hline \hline 2007 & $3.20 \%$ & $2.50 \%$ & $1.80 \%$ & $3.50 \%$ & $4.80 \%$ & $1.50 \%$ & $2.50 \%$ & $3.70 \%$ \\
2008 & $1.10 \%$ & $-0.30 \%$ & $-0.30 \%$ & $-0.40 \%$ & $-2.60 \%$ & $-1.00 \%$ & $0.20 \%$ & $1.10 \%$ \\
2009 & $-5.60 \%$ & $-4.30 \%$ & $-2.80 \%$ & $-4.40 \%$ & $-6.40 \%$ & $-5.50 \%$ & $-3.00 \%$ & $-3.60 \%$ \\
2010 & $4.10 \%$ & $1.90 \%$ & $2.50 \%$ & $-5.40 \%$ & $-0.30 \%$ & $1.70 \%$ & $1.90 \%$ & $0.00 \%$ \\
2011 & $3.60 \%$ & $1.60 \%$ & $1.60 \%$ & $-8.90 \%$ & $2.80 \%$ & $0.60 \%$ & $-1.80 \%$ & $-0.60 \%$ \\
2012 & $0.40 \%$ & $0.70 \%$ & $2.30 \%$ & $-6.60 \%$ & $-0.30 \%$ & $-2.80 \%$ & $-4.00 \%$ & $-2.10 \%$ \\
2013 & $0.10 \%$ & $1.70 \%$ & $2.20 \%$ & $-3.90 \%$ & $0.20 \%$ & $-1.70 \%$ & $-1.60 \%$ & $-1.20 \%$ \\
2014 & $1.60 \%$ & $2.80 \%$ & $2.40 \%$ & $0.80 \%$ & $4.80 \%$ & $-0.40 \%$ & $0.90 \%$ & $1.40 \%$ \\
\hline & Germany & UK & USA & Greece & Ireland & Italy & Portugal & Spain \\
\hline $2007 / 09$ & $-1.40 \%$ & $-2.10 \%$ & $-1.30 \%$ & $-1.40 \%$ & $-4.20 \%$ & $-5.10 \%$ & $-0.30 \%$ & $1.20 \%$ \\
$2010 / 14$ & $9.80 \%$ & $8.70 \%$ & $11.10 \%$ & $-24.00 \%$ & $7.10 \%$ & $-2.60 \%$ & $-4.70 \%$ & $-2.50 \%$ \\
\hline
\end{tabular}


A 6: Annual Effect of Fiscal Policy Using QS Multipliers with Output Gap-based Definition of Recession

\begin{tabular}{rrrrrrrrr}
\hline Year & Germany & UK & US & Greece & Ireland & Italy & Portugal & Spain \\
\hline \hline 2007 & $0.10 \%$ & $0.20 \%$ & $0.44 \%$ & $1.14 \%$ & $1.33 \%$ & $-0.21 \%$ & $-0.20 \%$ & $0.95 \%$ \\
2008 & $0.55 \%$ & $0.73 \%$ & $0.78 \%$ & $0.20 \%$ & $1.42 \%$ & $0.29 \%$ & $0.18 \%$ & $1.30 \%$ \\
2009 & $1.82 \%$ & $1.60 \%$ & $1.15 \%$ & $1.49 \%$ & $0.48 \%$ & $0.20 \%$ & $2.74 \%$ & $3.05 \%$ \\
2010 & $1.05 \%$ & $-0.68 \%$ & $1.03 \%$ & $-2.17 \%$ & $-3.99 \%$ & $0.40 \%$ & $-0.97 \%$ & $0.09 \%$ \\
2011 & $0.24 \%$ & $-1.25 \%$ & $-0.87 \%$ & $-6.51 \%$ & $-1.04 \%$ & $-2.07 \%$ & $-3.71 \%$ & $-0.62 \%$ \\
2012 & $0.92 \%$ & $0.19 \%$ & $-0.52 \%$ & $-3.91 \%$ & $-0.62 \%$ & $-1.66 \%$ & $-6.24 \%$ & $-3.66 \%$ \\
2013 & $1.04 \%$ & $-0.76 \%$ & $-0.78 \%$ & $-4.41 \%$ & $-0.52 \%$ & $-0.78 \%$ & $0.72 \%$ & $-1.12 \%$ \\
2014 & $1.21 \%$ & $0.51 \%$ & $0.02 \%$ & $-0.24 \%$ & $1.15 \%$ & $-0.67 \%$ & $-0.74 \%$ & $-0.14 \%$ \\
\hline
\end{tabular}

A 7: Annual Effect of Fiscal Policy Using GR Multipliers with Output Gap-based Definition of Recession

\begin{tabular}{lrrrrrrrr}
\hline Country & Germany & UK & US & Greece & Ireland & Italy & Portugal & Spain \\
\hline \hline 2007 & $0.02 \%$ & $0.06 \%$ & $0.36 \%$ & $0.15 \%$ & $-3.62 \%$ & $-0.20 \%$ & $0.04 \%$ & $0.18 \%$ \\
2008 & $0.07 \%$ & $0.16 \%$ & $1.99 \%$ & $-0.09 \%$ & $-7.58 \%$ & $0.44 \%$ & $-0.13 \%$ & $1.19 \%$ \\
2009 & $2.44 \%$ & $4.70 \%$ & $7.06 \%$ & $0.67 \%$ & $-1.96 \%$ & $2.48 \%$ & $4.70 \%$ & $7.26 \%$ \\
2010 & $0.60 \%$ & $-0.34 \%$ & $2.01 \%$ & $-0.69 \%$ & $-0.49 \%$ & $0.20 \%$ & $2.12 \%$ & $0.51 \%$ \\
2011 & $0.17 \%$ & $-0.84 \%$ & $-2.01 \%$ & $-5.22 \%$ & $-0.12 \%$ & $-1.23 \%$ & $-3.99 \%$ & $-1.75 \%$ \\
2012 & $0.29 \%$ & $1.00 \%$ & $-1.14 \%$ & $-3.74 \%$ & $0.98 \%$ & $-1.31 \%$ & $-4.75 \%$ & $-3.76 \%$ \\
2013 & $0.54 \%$ & $-0.58 \%$ & $-1.02 \%$ & $-5.61 \%$ & $0.32 \%$ & $-0.05 \%$ & $0.85 \%$ & $-1.05 \%$ \\
2014 & $0.86 \%$ & $0.79 \%$ & $-0.13 \%$ & $1.96 \%$ & $2.30 \%$ & $0.23 \%$ & $-1.34 \%$ & $-0.11 \%$ \\
\hline
\end{tabular}

